\title{
The role of emotion regulation in childhood obesity: implications for prevention and treatment
}

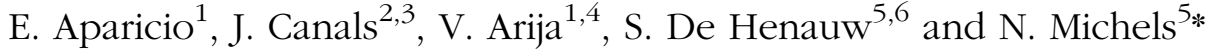 \\ ${ }^{1}$ Faculty of Medicine and Health Sciences, Nutrition and Mental Health Research Group (NUTRISAM), Institut de Investigació \\ Sanitaria Pere Virgili (IISPV), Universitat Rovira i Virgili (URV), Reus, Spain \\ ${ }^{2}$ Faculty of Education Sciences and Psychology, Nutrition and Mental Health Research Group (NUTRISAM), Institut de \\ Investigació Sanitaria Pere Virgili (IISPV), Universitat Rovira i Virgili, Tarragona, Spain \\ ${ }^{3}$ Research Center for Behavioral Assessment, CRAMC, Department of Psychology, URV, Tarragona, Spain \\ ${ }^{4}$ Institut d'Investigació en Atenció Primària, IDIAP Jordi Gol i Gurina, Catalonia, Spain \\ ${ }^{5}$ Department of Public Health, Faculty of Medicine and Health Sciences, Ghent University; Ghent, Belgium \\ ${ }^{6}$ Department of Health Sciences, Vesalius, University College Ghent, Ghent, Belgium
}

\section{Abstract}

Stress and negative emotions pose a major threat to public health, by increasing the risk of obesity. Since the management process for emotions (emotion regulation; ER) is developed in childhood, we present a novel conceptual framework model for the role of ER in the prevention and treatment of childhood obesity. A narrative review of the literature by electronic database search (MEDLINE, Web of Knowledge and Scopus) was conducted of observational and interventional/experimental literature on ER and obesity and the underlying concepts. We also present an overview of ER intervention techniques. Our model indicates that childhood ER is a link between stress and obesity. Stress along with ineffective ER leads to abnormal cortisol patterns, emotional eating, sedentary lifestyle, reduction of physical activity, and sleep problems. Simultaneously, a healthy lifestyle could show benefits on ER and in developing adaptive ER strategies. In the development of obesity and ER, parents also play a role. By contrast, effective ER skills decrease obesity-related unhealthy behaviour and enhance protective factors, which boost health. The literature contains some observational studies of children but very few intervention studies, most of which are pilot or on-going studies. In conclusion, encouraging effective ER could be a useful new approach for combating and treating childhood obesity. Future ER intervention studies are needed to confirm the validity of this model in children.

\section{Key words: Emotion regulation: Obesity: Prevention: Treatment: Children}

\section{Introduction}

The epidemic of overweight and obesity in children observed in recent years calls for a better understanding of the associated risk factors ${ }^{(1)}$. It is generally accepted that the main lifestyle factors related to the rising prevalence of obesity derive from an imbalance in energy homeostasis caused by increased energy intake and/or sedentary behaviour. Despite lifestyle-based campaigns and interventions in children, adolescents and their parents, the prevalence of obesity has not decreased ${ }^{(2)}$. Therefore, new approaches are needed for prevention and treatment.

The potential role of psychological and emotional distress in obesity development has been less extensively researched ${ }^{(3)}$, but a generally positive relationship was found between negative affect or stress in children and weight gain (see Table 1$)^{(4-27)}$. This is particularly relevant because mental disorders affect $10-20 \%$ of children and adolescents worldwide $^{(28)}$ and $47.7 \%$ of the children in a European study presented psychosomatic or emotional symptoms ${ }^{(29)}$. Being more vulnerable to develop mental disorders or being more susceptible to stress could be followed by a poor emotion regulation $(\mathrm{ER})^{(30)}$. As it has been suggested in adult populations, a poor ER may entail the use of maladaptive strategies to manage with emotions for example, by using food ${ }^{(31-33)}$. Since the manner how they deal with emotions might contribute to obesity, children should acquire efficient emotion management at an early age. Research into the relationship between ER and energy homeostasis could be extremely useful for designing preventive and treatment-based obesity programmes.

The present review discusses current literature on ER and obesity in childhood. Based on a non-systematic and narrative review, we present a novel conceptual framework for the role of ER in weight gain and obesity, discussing the potential underlying factors and their implications for prevention and treatment.

\footnotetext{
Abbreviation: ER, emotion regulation.

* Corresponding author: Nathalie Michels, email nathalie.michels@ugent.be
} 
Table 1. Overview of studies about child and adolescent stress and negative affect as predictors of weight gain/overweight/obesity: prospective studies

\begin{tabular}{|c|c|c|c|c|c|c|c|}
\hline $\begin{array}{l}\text { First author } \\
\text { and year }\end{array}$ & Country & $\begin{array}{l}\text { Follow-up } \\
\text { duration } \\
\text { (years) }\end{array}$ & $\begin{array}{l}\text { Sample }(n) / \mathrm{sex} \\
(\% \text { girls })\end{array}$ & $\begin{array}{l}\text { Age or grades at } \\
\text { baseline }\end{array}$ & Psychological predictor: measurement tool & Adiposity measures & Results \\
\hline Goodman $(2002)^{(4)}$ & USA & 1 & $9374(48.6 \%)$ & $\begin{array}{l}\text { Grades } 7-12(12-18 \\
\text { years) }\end{array}$ & Depressive symptoms: CES-D & Measured and self-reported: BMI & $\begin{array}{l}\text { Depressive symptoms increased risk of obesity in obese and non-obese } \\
\text { subjects }\end{array}$ \\
\hline Anderson $(2011)^{(5)}$ & USA & 2 & $918(100 \%)$ & Grade 6 (11 years) & Depressive symptoms: CES-D & Measured: BMI & $\begin{array}{l}\text { Depressive symptoms associated with greater likelihood of obesity in white } \\
\text { females }\end{array}$ \\
\hline Bradley $(2008)^{(6)}$ & USA & 11 & $1254(48 \%)$ & 2 years to grade 6 & $\begin{array}{l}\text { Externalising and internalising problems: } \\
\text { CBCL }\end{array}$ & Measured: BMI & $\begin{array}{l}\text { Positive association between externalising or internalising problems and } \\
\text { BMI }\end{array}$ \\
\hline van Jaarsveld $(2009)^{(7)}$ & UK & 5 & $4065(42 \%)$ & $11-12$ years & $\begin{array}{l}\text { Perceived stress at a single time point and } \\
\text { mean perceived stress over } 5 \text { years: PSS } \\
\text { short form }\end{array}$ & Measured: waist, BMI & $\begin{array}{l}\text { Perceived stress associated with } \Delta \text { BMI z-scores, } \Delta \text { waist } \\
\text { High mean of stress associated with } 5 \text {-year BMI z-score trajectory and } \\
5 \text {-year waist } z \text {-score trajectory }\end{array}$ \\
\hline Midei $(2009)^{(8)}$ & USA & 3 & $160(48.7 \%)$ & 14 years & $\begin{array}{l}\text { Trait anxiety symptoms: STAIC } \\
\text { Anger and anxiety: Cook-Medley Hostility } \\
\text { Scale }\end{array}$ & Measured: waist:hip ratio & Higher anger associated with increased waist:hip ratio \\
\hline Tanofsky-Kraff $(2006)^{(9)}$ & USA & 4.2 & $146(52 \%)$ & $6-12$ years & $\begin{array}{l}\text { Depressive symptoms: CDI Child Symptom } \\
\text { Inventory }\end{array}$ & Measured: body fat mass & No association \\
\hline Rofey $(2009)^{(10)}$ & USA & 3 & $285(49 \%)$ & $8-18$ years & $\begin{array}{l}\text { Depression and anxiety: K-SADS-E, } \\
\text { K-SADS-P, K-SADS-PL (DSM-III and } \\
\text { DMS-IV criteria) }\end{array}$ & Measured: BMI & $\begin{array}{l}\text { Females: depression and anxiety associated with high BMI } \\
\text { Males: anxiety associated with high BMI } \\
\text { No association with depression }\end{array}$ \\
\hline Aparicio $(2013)^{(11)}$ & Spain & 3 & $229(62 \%)$ & 10 years & $\begin{array}{l}\text { Depression and anxiety: SCARED, CDI } \\
\text { MINI-KID (DSM-IV criteria) }\end{array}$ & $\begin{array}{l}\text { Measured: BMI, waist, body fat } \\
\text { mass }\end{array}$ & $\begin{array}{l}\text { Females: anxiety symptoms associated with } \triangle B M I \text { and body fat mass; } \\
\text { depression disorder associated with } \triangle \text { waist } \\
\text { Males: anxiety and depression associated with } \triangle B M I \text { and waist } \\
\text { Inverse relationship observed between major depression disorder and BMI }\end{array}$ \\
\hline Larsen $(2014)^{(12)}$ & Netherlands & 3 & $1465(49.4 \%)$ & 11.4-16.9 years & Depressive symptoms: CES-D & Measured: BMI & $\begin{array}{l}\text { Females: depressive symptoms associated with higher BMI } z \text {-score } \\
\text { Males: no association }\end{array}$ \\
\hline Rhew $(2008)^{(13)}$ & USA & 1 & $\begin{array}{l}466(46 \cdot 2 \%) ; 165 \\
\text { subsample } \\
\text { BMI measures }\end{array}$ & 12 years mean & Depressive symptoms: MFQ & Measured and self-reported: BMI & $\begin{array}{l}\text { BMI self-reported: females: depressive symptoms associated with lower } \\
\text { BMI than non-depressive symptoms; females: depressive symptoms } \\
\text { associated with higher BMI than non-depressive symptoms } \\
\text { BMI measures: no association }\end{array}$ \\
\hline Michels $(2015)^{(14)}$ & Belgium & 2 & $316(50 \%)$ & $5-12$ years & $\begin{array}{l}\text { Negative events: Coddington Life Events } \\
\text { Scale for Children } \\
\text { Negative emotions: anger, anxiety, sadness } \\
\text { Behavioural problems: SDQ }\end{array}$ & $\begin{array}{l}\text { Measured: BMI, waist:height ratio, } \\
\text { fat percentage }\end{array}$ & $\begin{array}{l}\text { Stress positively or negatively associated with adiposity depending on } \\
\text { cortisol and lifestyle, which had a moderating effect }\end{array}$ \\
\hline Stice $(2005)^{(15)}$ & USA & 4 & $496(100 \%)$ & $11-15$ years & $\begin{array}{l}\text { Depressive symptoms: SADS for School- } \\
\text { Age Children }\end{array}$ & Measured: BMI & No association \\
\hline Jansen $(2008)^{(16)}$ & Netherlands & 3 & $787(49 \%)$ & $9-10$ years & $\begin{array}{l}\text { Depressive symptoms and social anxiety: } \\
\text { Rotterdam Youth Health Monitor RYM } \\
\text { questionnaire, Short Depression } \\
\text { Inventory for Children, Dutch social } \\
\text { anxiety scale for children }\end{array}$ & Measured: BMI & No association \\
\hline Chen $(2009)^{(17)}$ & USA & 4 & $543(100 \%)$ & 10 years & $\begin{array}{l}\text { Depressive symptoms: CSI (reported by } \\
\text { parents) (DSM-IV criteria) }\end{array}$ & Measured: BMI & No association \\
\hline Hammerton $(2014)^{(18)}$ & UK & $1-2$ & $289(57.1 \%)$ & $9-17$ years & $\begin{array}{l}\text { Depressive disorder: CAPA (DSM-IV } \\
\text { criteria) }\end{array}$ & Measured: BMI & No association \\
\hline $\begin{array}{l}\text { Child or adolescent emo } \\
\text { Pine (1997) }\end{array}$ & $\begin{array}{l}\text { al problems } \\
\text { USA }\end{array}$ & $\begin{array}{l}\text { alt over } \\
8-10\end{array}$ & $\begin{array}{l}\text { obesity } \\
644(52 \%)\end{array}$ & $9-18$ years & Depressive symptoms: CES-D (DSM-III & Self-reported: BMI & Depressive symptoms associated with higher BMI \\
\hline Pine $(2001)^{(20)}$ & USA & 10 & $177(50.2 \%)$ & $6-17$ years & $\begin{array}{l}\text { Depressive symptoms: SADS for School- } \\
\text { Age Children and SADS Lifetime } \\
\text { Disorders version }\end{array}$ & Self-reported: BMI & Depressive symptoms associated with high BMI in adulthood \\
\hline $\begin{array}{l}\text { Franko }(2005)^{(21)} \\
\text { Anderson }(2006)^{(22)}\end{array}$ & $\begin{array}{l}\text { USA } \\
\text { USA }\end{array}$ & 22 & $\begin{array}{l}1554(100 \%) \\
661(53 \%)\end{array}$ & $\begin{array}{l}16 \text { years } \\
15 \text { years mean }(9-18 \\
\text { years })\end{array}$ & $\begin{array}{l}\text { Depressive symptoms: CES-D } \\
\text { Depression and anxiety: DISC (DSM-IV } \\
\text { criteria) }\end{array}$ & $\begin{array}{l}\text { Measured and self-reported: BMI } \\
\text { Self-reported: BMI }\end{array}$ & $\begin{array}{l}\text { Depressive symptoms associated with high BMI and with obesity } \\
\text { Females: positive relationship } \\
\text { Males: no association }\end{array}$ \\
\hline Richardson $(2003)^{(23)}$ & USA & 10 & $881(48 \%)$ & $11-15$ years & Depression disorder: DISC (DSM-III criteria) & Measured: BMI & $\begin{array}{l}\text { Females: depression in later adolescence increases risk of obesity in } \\
\text { adulthood; no association in early adolescence }\end{array}$ \\
\hline Duarte $(2010)^{(26)}$ & Finland & $18-23$ & 2209 (0 \%) & 8 years & $\begin{array}{l}\text { Depressive symptoms: depression, CDI } \\
\text { Emotion problems (Rutter questionnaire) }\end{array}$ & Measured: BMI & No associatic \\
\hline Wickrama $(2009)^{(27)}$ & USA & 6 & $11404(52 \%)$ & $12-19$ years & Depressive symptoms: CES-D & Self-reported: BMI & No association \\
\hline
\end{tabular}

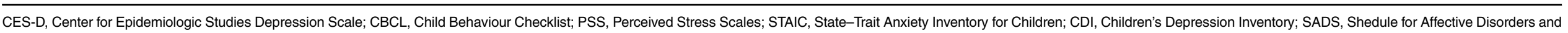

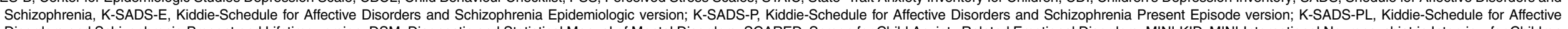

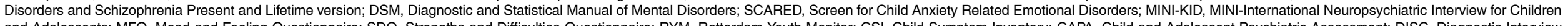

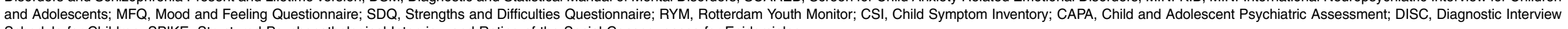
Schedule for Children; SPIKE, Structured Psychopathological Interview and Rating of the Social Consequences for Epidemiology. 


\section{Emotion regulation}

\section{Definition of emotion regulation}

ER is a growing field within psychology and holds a central role in all the psychological areas including health, development, clinical, social and personality as well as in a variety of other disciplines ${ }^{(34)}$. ER can be broadly defined as the set of strategies used to maintain a positive affective status or improve or suppress a negative affective status in stressful and non-stressful circumstances $^{(35,36)}$. Nevertheless, there is no single, unified approach of ER. One of the first definitions was given by Thompson $^{(37)}$, who defined ER as 'the extrinsic and intrinsic process by which individuals are able to monitor, evaluate and modify their emotions to accomplish their goal ${ }^{,(37)}$. This concept has been amplified to describe a process for modifying and maintaining feelings, behaviours and psychological features of emotions. In other words, ER refers to attempts to influence which emotions one has and how one experiences or expresses these emotions ${ }^{(34,38)}$. Also, the Adaptive Coping with Emotions (ACE) model has explained how emotion dysregulation can occur and provided tools to enhance effective $\mathrm{ER}^{(39)}$. This new model is based on the acquisition of skills which help to maintain or restore mental health and to address aversive emotions. To summarise, ER is a common process that depends on certain skills and is frequently used in daily life to ensure personal well-being.

\section{Psychological factors related to emotion regulation}

ER is related to and interacts with other psychological factors. According to Gross ${ }^{(34)}$, ER along with coping and mood regulation concepts shape the affective regulation term. Coping is understood as responses to alleviate stress, whereas ER is conceptualised as an ongoing process that occurs under both stressful and non-stressful circumstances and is organised around specific emotions (i.e. sadness, fear, anger) and includes efforts to up- or down-regulate both positive and negative emotions $^{(35,36)}$. In contrast, mood refers to less specific and longer-lasting experiences and seems to be influenced by cognition more than by behaviour processes. Mood regulation may be distinguished from ER by its predominant focus on altering subjective feeling states ${ }^{(34)}$. Therefore, it is suggested that there is a considerable overlap among these regulatory processes $^{(34)}$.

Other factors are executive functions, which are important in the management of cognitive and behavioural processes including working memory, reasoning, task flexibility, inhibition capacity and impulsivity, problem solving, planning and execution $^{(40)}$. Some studies have reported a direct link between executive function abilities and specific ER capacities ${ }^{(41)}$. Interestingly, impairments of executive function have been reported in overweight adults ${ }^{(42)}$ and also in children ${ }^{(43,44)}$ since it might contribute to eating styles ${ }^{(45)}$. Indeed, childhood disorders characterised by impaired executive function, such as attention-deficit/hyperactivity disorder, are associated with overeating and obesity ${ }^{(46,47)}$.

Self-regulation is a key factor related to ER and executive function that can be understood to include effortful control and impulsivity control. The concept of effortful control encompasses the abilities to inhibit or activate behaviours for the benefit of long-term goals; impulsivity is characterised by high reward sensitivity and a high deficit of response inhibition. These factors have a direct relationship with dietary restraint, in which efforts are made to suppress rewardbased impulses to eat in pursuing long-term weight goals ${ }^{(48)}$. Several studies in children have found that an increase in impulsivity, a decrease in inhibitory control and a higher reward sensitivity are associated with unhealthier food choices and overweight ${ }^{(49-53)}$.

\section{Emotion regulation in children}

Childhood and adolescence are two critical periods in the development of executive function, behaviour-regulation skills and consequently ER strategies. However, newborns and infants are capable of regulating their emotions. From the first days of life, using a neonatal self-regulation assessment, individual differences have been found in controlling negative emotions in a stressful environment ${ }^{(54)}$. At preschool age, children acquire a large range of strategies to manage their own mood and this ability is established in adolescence ${ }^{(55)}$.

Parental influence is essential in the process of ER development, where parents serve as role models and influence the family atmosphere ${ }^{(56)}$. Children learn ER skills early through interactions with their parents or caregivers, as well as through family factors like family expressivity or communication ${ }^{(57)}$. Also, a negative parental response to children's emotions teaches children to avoid rather than understand emotions and has been linked to inappropriate ER strategies ${ }^{(58)}$. Parenting styles characterised by 'high warmth and high control' have an influence on children's effective ER leading to greater self-efficacy, self-discipline and successful dealing with challenges ${ }^{(56,59)}$.

ER is essential to healthy psychological functioning. In children, it is an important predictor of risk behaviours ${ }^{(60,61)}$ and mental problems ${ }^{(60)}$, particularly those related to emotional problems ${ }^{(62)}$. Children who do not develop adequate ER strategies will be less able to survive in new environments where they face conflicts. The use of maladaptive ER can generate a vicious circle, since it may increase negative emotions which are involved in developing maladaptive strategies ${ }^{(39)}$.

\section{Emotion regulation skills}

According to the theory of adaptive coping cited above ${ }^{(39)}$, adaptive ER is conceptualised as a situation-dependent interaction between ER skills. The regulatory skills in this model are: awareness of emotions (i.e. the ability to identify and label emotions), understanding emotions (i.e. the ability to identify the causes and maintaining factors of emotions); acceptance and tolerance (i.e. the ability to accept and tolerate negative emotions when necessary); self-support and self-compassion (i.e. the ability to provide effective self-support and self-compassion in distressing situations by self-soothing, self-encouragement and active self-coaching); modifying emotions (i.e. the ability to modify emotions in an adaptive way, which includes self-efficacy) and 
readiness to confront (i.e. the ability to address situations likely to cause negative emotions). Enhancing or acquiring these skills helps in maintaining or restoring mental health and in approaching aversive emotions ${ }^{(63)}$.

\section{A new model for the role of emotion regulation in obesity development}

A discussion of findings in the field of ER and obesity is synthetised to provide evidence for the proposed model of the role of ER in obesity prevention and treatment. A schematic illustration of this model is given in Fig. 1.

ER strategies have been classified as ineffective/maladaptive $v$. effective/adaptive, based on their immediate effects on affect, behaviour and cognition ${ }^{(30,64)}$. Presence of stress or negative life events could cause emotional dysregulation and therefore increase the vulnerability to develop maladaptive ER strategies in modulating the negative emotion. Thus, it is not only the fact that individuals experience negative emotions but also the way in which they cope with them that may determine the emotional impact on weight gain.

Only very few observational studies have assessed the relationship between ER and obesity in children. Therefore, related factors such as executive function and self-control, which include similar aspects of ER, have also been included in the overview shown in Table $2^{(51,52,65-71)}$. Although the evidence is modest, better ER-related skills were associated with a healthier diet (more fruit/vegetables and less snack food, although not all studies reported significant findings), higher physical activity and, in some cases, a healthier weight status.

\section{Physiological mechanisms leading to obesity}

Studies have shown that stress can increase overweight and the related adverse metabolic consequences through neuroendocrine changes ${ }^{(72)}$. Repeated activation of the hypothalamicpituitary-adrenal (HPA) axis mediates stress responses and increases cortisol secretion. This chronic cortisol hypersecretion may cause fat to accumulate in the visceral adipose tissues ${ }^{(73)}$ through interaction with lipid homeostasis at several levels: lipolysis, adipogenesis, lipogenesis, and the regulation of circulating fatty acids ${ }^{(74)}$. However, intense acute or chronic stress might also lead to hypo-activation of the HPA axis, or hypocortisolism $^{(72)}$. The cortisol response to stress is complex, but both hypo- and hypercortisolism may be harmful. According to a meta-analysis, HPA activity depends on the personal response to stress, since cortisol output increases with distress and decreases in individuals with post-traumatic acute stress ${ }^{(75)}$. Recent research in schoolchildren indicates that stress is associated with hypercortisolism ${ }^{(76)}$. Additionally, other findings point out that maladaptive ER induces cortisol reactivity ${ }^{(77)}$.

Therefore, stress in combination with maladaptive coping strategies could lead to dysregulated cortisol secretion and obesity. Since cortisol is appetite-stimulating, it also increases appetite and the attraction to sweet and fatty foods, mainly by stimulating reward pathways or by influencing other hormones $^{(76,78)}$.

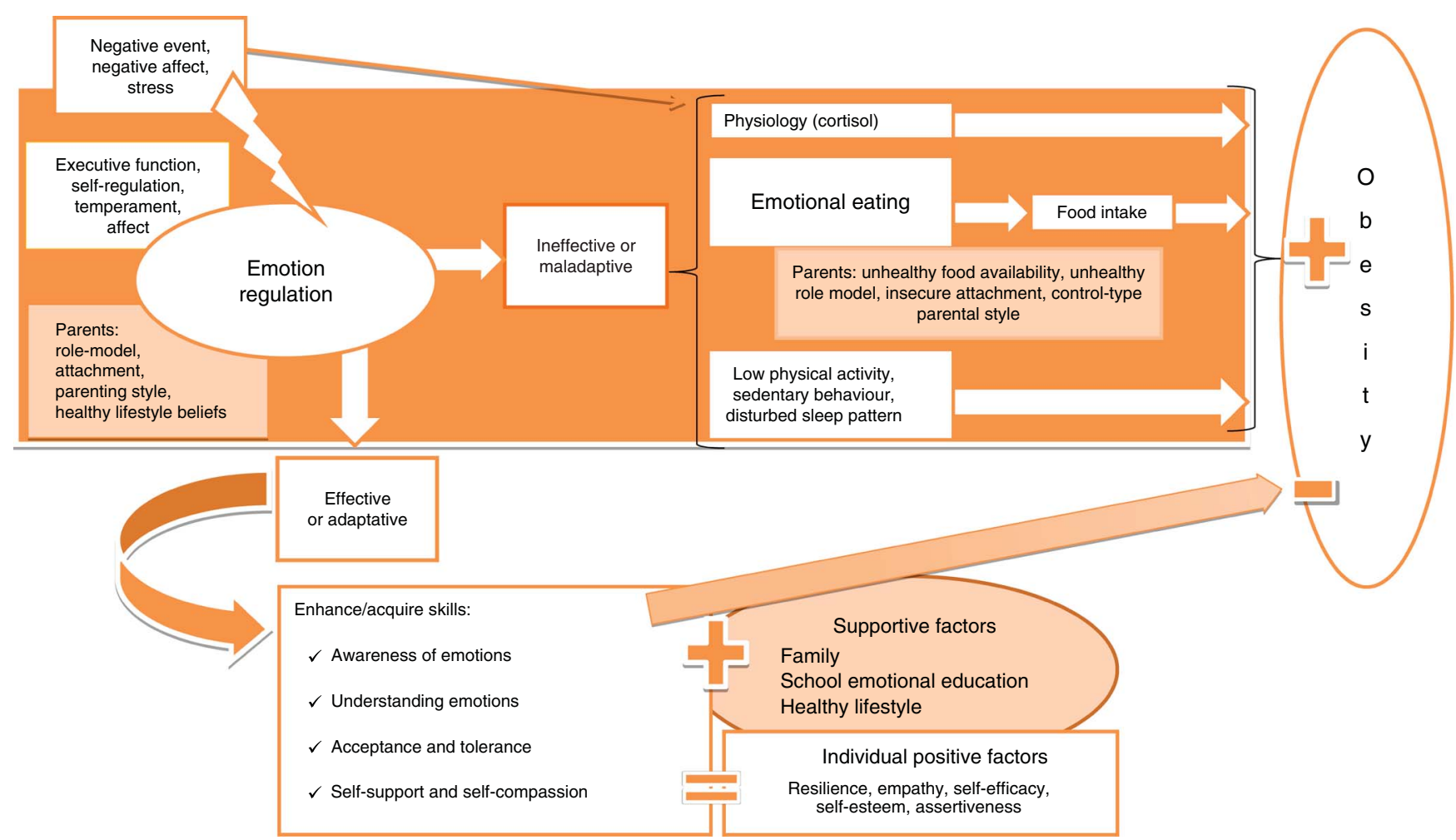

Fig. 1. Conceptual framework for the role of emotion regulation in the prevention and treatment of childhood obesity. For a colour figure, see the online version. 
Table 2. Emotion regulation or related terms as predictors of childhood weight gain/overweight/obesity: observational studies

\begin{tabular}{|c|c|c|c|c|c|c|c|}
\hline $\begin{array}{l}\text { First author and } \\
\text { year }\end{array}$ & Country & Type of study & $\begin{array}{l}\text { Sample }(n) / \\
\text { sex }(\% \text { girls })\end{array}$ & $\begin{array}{l}\text { Age or grade at } \\
\text { baseline }\end{array}$ & Emotion regulation predictor: measurement tool & $\begin{array}{l}\text { Outcome: adiposity-related measures or } \\
\text { obesity-related behaviour measures }\end{array}$ & Results \\
\hline Isasi $(2013)^{(65)}$ & USA & $\begin{array}{l}\text { Cross- } \\
\text { sectional }\end{array}$ & $612(58 \%)$ & 12 years & $\begin{array}{l}\text { Emotion regulation: soothability, sadness management, } \\
\text { anger management, assessed by three scales: } \\
\text { Self-efficacy for healthy eating } \\
\text { Self-efficacy for physical activity } \\
\text { Depressive symptoms }\end{array}$ & $\begin{array}{l}\text { Food intake: YAQ } \\
\text { Physical activity: Youth Risk Behaviour } \\
\text { Survey } \\
\text { Time spent in sedentary behaviours } \\
\text { Anthropometry: measured BMI }\end{array}$ & $\begin{array}{l}\text { Stronger emotion regulation associated with higher intake } \\
\text { of fruit/vegetables and physical activity; association } \\
\text { mediated by self-efficacy. No association with BMI }\end{array}$ \\
\hline $\begin{array}{l}\text { Graziano } \\
(2010)^{(51)}\end{array}$ & USA & $\begin{array}{l}\text { Longitudinal } \\
3 \cdot 5 \text {-year } \\
\text { follow-up }\end{array}$ & $57(43.8 \%)$ & 2 years & $\begin{array}{l}\text { Emotion regulation: laboratory task: videotapes of } \\
\text { frustration tasks (Prize in the Box and High Chair) } \\
\text { Inhibitory control/reward sensitivity: delay of gratification } \\
\text { task, assessment of the overall total time touching gift } \\
\text { Sustained attention: children were instructed to watch a 5- } \\
\text { min segment of the videotape 'Spot', overall duration of } \\
\text { attention was measured } \\
\text { Child behaviour problems: CBCL }\end{array}$ & Measured: BMI & $\begin{array}{l}\text { Maladaptive emotion regulation and inhibitory control/ } \\
\text { reward sensitivity predicted more extreme weight } \\
\text { problems at } 5.5 \text { years }\end{array}$ \\
\hline $\begin{array}{l}\text { Graziano } \\
\quad(2013)^{(52)}\end{array}$ & USA & $\begin{array}{l}\text { Longitudinal } \\
7 \text {-year } \\
\text { follow-up }\end{array}$ & $195(58.4 \%)$ & 2 years & $\begin{array}{l}\text { Laboratory task: as above, except that CBCL was } \\
\text { replaced by the Toddler Behaviour Assessment } \\
\text { Questionnaire } \\
\text { Statistical method to reduce data: } \\
\text { Factor 1, self-regulation (including emotion regulation) } \\
\text { Factor 2, temperament; pleasure }\end{array}$ & Measured: BMI & $\begin{array}{l}\text { Toddlers with better self-regulation skills at age } 2 \text { years } \\
\text { had lower BMI z-scores at } 10 \text { years old and were less } \\
\text { likely to show an increase in BMI z-scores from } 4 \text { to } 10 \\
\text { years }\end{array}$ \\
\hline Isasi $(2011)^{(66)}$ & USA & $\begin{array}{l}\text { Cross- } \\
\text { sectional }\end{array}$ & $1771(51 \%)$ & 12 years & $\begin{array}{l}\text { Self-regulation measures: } \\
\text { Multiple indicators of effortful: planfulness, problem } \\
\text { solving, soothability, selff-reinforcement } \\
\text { Multiple indicators of dysregulation: impulsivity, } \\
\text { impatience, immediate gratification, anger ability, } \\
\text { distractibility, self-criticism } \\
\text { Self-efficacy for healthy eating } \\
\text { Self-efficacy for physical activity }\end{array}$ & $\begin{array}{l}\text { Dietary intake: short FFQ } \\
\text { Physical activity and sedentary behaviour: } \\
\text { Youth Risk Behaviour Survey } \\
\text { Anthropometry: measured BMI }\end{array}$ & $\begin{array}{l}\text { Effortful control had a positive indirect effect on fruit and } \\
\text { vegetable intake, mediated by self-efficacy } \\
\text { Effortful control had a positive indirect effect on physical } \\
\text { activity, mediated by selffe-fficacy } \\
\text { Dysregulation had direct effects on higher intake of junk } \\
\text { food/snacks and time spent in sedentary behaviours }\end{array}$ \\
\hline Wills $(2007)^{(67)}$ & USA & $\begin{array}{l}\text { Cross- } \\
\text { sectional }\end{array}$ & $539(48 \%)$ & $\begin{array}{c}14.6 \text { years } \\
\text { (mean) }\end{array}$ & $\begin{array}{l}\text { Self-control measures: } \\
\text { Good self-control: soothability, planfulness, problem } \\
\text { solving, cognitive effort, future time perspective, self- } \\
\text { reinforcement } \\
\text { Poor self-control: distractibility, impulsiveness, anger } \\
\text { ability, tension maintenance, impatience, present time } \\
\text { orientation, negative self-management }\end{array}$ & $\begin{array}{l}\text { Dietary intake: FFQ } \\
\text { Physical activity and sedentary behaviour: } \\
\text { Youth Risk Behaviour Survey }\end{array}$ & $\begin{array}{l}\text { Good self-control was related to more fruit and vegetable } \\
\text { intake, more participation in sports, and less sedentary } \\
\text { behaviour } \\
\text { Poor self-control was related to more saturated fat intake } \\
\text { and less vigorous exercise }\end{array}$ \\
\hline Riggs $(2010)^{(68)}$ & USA & $\begin{array}{l}\text { Longitudinal } \\
\text { 4-month } \\
\text { follow-up }\end{array}$ & $184(52 \%)$ & 9.3 years (mean) & $\begin{array}{l}\text { Executive cognitive function: } \\
\text { BRIEF-SR (including a subscale of emotion control; } \\
\text { inhibitory control; working memory; organisation of } \\
\text { materials) }\end{array}$ & $\begin{array}{l}\text { Dietary intake: FFQ } \\
\text { Physical activity: Physical Activity } \\
\text { Questionnaire for Older Children }\end{array}$ & $\begin{array}{l}\text { Baseline executive cognitive function was associated with } \\
\text { more fruit/vegetable intake and physical activity } \\
4 \text { months later; no association with snack food intake }\end{array}$ \\
\hline Riggs $(2012)^{(69)}$ & USA & $\begin{array}{l}\text { Cross- } \\
\text { sectional }\end{array}$ & $1587(49 \%)$ & 9.3 years & $\begin{array}{l}\text { Executive cognitive function: } \\
\text { BRIEF-SR (including a subscale of emotion control; } \\
\text { inhibitory control; working memory; organisation of } \\
\text { materials) }\end{array}$ & $\begin{array}{l}\text { Dietary intake: FFQ } \\
\text { Physical activity: Physical Activity } \\
\text { Questionnaire for Older Children }\end{array}$ & $\begin{array}{l}\text { Executive cognitive function was negatively associated } \\
\text { with high-energy snack food intake and sedentary } \\
\text { behaviour } \\
\text { Executive cognitive function was positively associated } \\
\text { with fruit and vegetable intake and physical activity }\end{array}$ \\
\hline Riggs $(2010)^{(70)}$ & USA & $\begin{array}{l}\text { Cross- } \\
\text { sectional }\end{array}$ & $107(54 \%)$ & 9.4 years & $\begin{array}{l}\text { Executive cognitive function: } \\
\text { BRIEF-SR (including a subscale of emotional control; } \\
\text { inhibitory control; working memory; organisation of } \\
\text { materials) }\end{array}$ & $\begin{array}{l}\text { Dietary intake: } \mathrm{FFQ} \\
\text { Physical activity: Physical Activity } \\
\text { Questionnaire for Older Children }\end{array}$ & $\begin{array}{l}\text { Executive cognitive function was negatively related to } \\
\text { snack food intake, but not significantly related to fruit } \\
\text { and vegetable intake }\end{array}$ \\
\hline $\begin{array}{l}\text { Hughes } \\
\qquad(2015)^{(71)}\end{array}$ & USA & $\begin{array}{l}\text { Cross- } \\
\text { sectional }\end{array}$ & $187(47.6 \%)$ & 4.7 years & $\begin{array}{l}\text { Eating self-regulation: } \\
\text { Laboratory task: eating in the absence of hunger } \\
\text { Questionnaire: CEBQ (satiety responsiveness and food } \\
\text { responsiveness) } \\
\text { Non-eating self-regulation (self-regulation, executive } \\
\text { function, emotion regulation): } \\
\text { Laboratory task: tapping task, flexible item selection task, } \\
\text { delay of gratification } \\
\text { Gift delay task } \\
\text { Questionnaire: CBQ (effortful control) }\end{array}$ & Anthropometry: measured BMI & $\begin{array}{l}\text { Eating self-regulation was associated with BMI, but not } \\
\text { other types of self-regulation }\end{array}$ \\
\hline
\end{tabular}

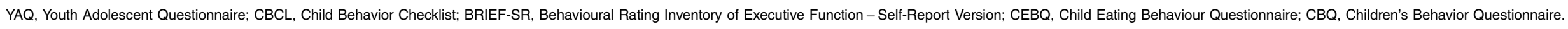




\section{Emotional eating: a mediator between emotional} dysregulation and obesity

Emotional eating and stress/emotions. In a stressful situation, some individuals will use maladaptive coping strategies such as eating mainly highly palatable and high-energy food to suppress negative emotions and stress ${ }^{(33)}$. According to the theory of emotional eating, the eating behaviour to deal with emotions is defined as emotional eating ${ }^{(79)}$. A poor emotional regulation leads to emotional eating in adults ${ }^{(31,32,80)}$. Studies consistently report that emotional eating is often followed by negative emotions, also in children ${ }^{(81-85)}$. Consequently, emotional eating is the result of self-inability to regulate emotions, and this maladaptive strategy might underlie the relationship between emotional dysregulation and obesity by modifying dietary intake $^{(50,51,65)}$. Studies in children and adolescents have revealed an association between maladaptive ER strategies and emotional eating ${ }^{(83,86-88)}$. However, different maladaptive strategies of ER have been assessed in these studies and this may lead to bias in the results. Harrist et al. ${ }^{(86)}$ conducted a longitudinal study in 782 children and found that reactivity to anger and worry was consistently related to emotional eating. In this vein, maladaptive ER such as ruminative thinking increased the desire to eat in adolescents ${ }^{(88)}$.

Emotional eating and food intake. Emotional eating leads to an unhealthier diet since it is suggested that food with high energy density can ameliorate negative affect or stress ${ }^{(89)}$. As a result, emotional eating increases the intake of sweet and fatty foods, or 'comfort food' ${ }^{(90-92)}$. In experimental studies, emotional eaters have been found to consume more sweet and fatty foods ${ }^{(93-95)}$ in response to stress. Although there are fewer studies of child populations, the conclusions are often similar: emotional eating was associated with high intake of sweet and/ or fatty food in both observational ${ }^{(85,96-98)}$ and laboratory studies ${ }^{(95,99-101)}$. Although these observational studies were cross-sectional, several were conducted on large samples and showed strong association ${ }^{(96-99)}$. Moreover, sex appeared to play a role in the effect of emotional eating on food choices since females often tend to eat more sweet and fatty food. However, the possible interaction of sex and age remains unclear.

Emotional eating and obesity. Since emotional eating is related to less healthy dietary intake, it has been longitudinally linked to weight gain and obesity, especially in females ${ }^{(102,103)}$. Although no significant relationship was observed in a small number of studies ${ }^{(104)}$, other studies identified a significant percentage of emotional eating in overweight children $^{(81,85,105,106)}$. Braet et al. ${ }^{(105)}$ showed that in a large sample of children and adolescents $10.5 \%$ of overweight children reported high scores of emotional eating. Especially in adolescence, the relationship becomes stronger in overweight females $^{(105)}$ with loss of control ${ }^{(81,106)}$. Interestingly, obese individuals are also more vulnerable to emotional eating since, according to psychosomatic theory, they are unable to distinguish between hunger and negative emotions as a cause of their desire for food ${ }^{(107)}$. In addition, the cognitive load of coping with a negative emotion may overcome the self-regulation process so that obese individuals no longer maintain their selfcontrol. Therefore, emotional eating may have an important role in the development and maintaining of overweight and obesity.

Emotional eating and parental influence. Parents and family members influence children's food choices not only through food availability, eating patterns at home, and role modelling ${ }^{(108)}$, but also through other processes. Parental feeding practices could lead to unhealthy eating behaviours and childhood obesity ${ }^{(109,110)}$, since parents can pressure children to eat or restrict their diet or can use sweets as rewards or to change their temperament. Children also learn from their parents' behaviour, for example by using food to calm negative emotion. A laboratory study conducted on twenty-five preschool children and their mothers showed that children of mothers who use food for ER consume more sweet palatable foods in the absence of hunger ${ }^{(111)}$. Similarly, a cross-sectional study in 497 children and mothers found that maternal feeding behaviours affect emotional eating in children ${ }^{(112)}$. These practices may have a negative impact on the development of self-regulation of eating, since children learn to use food as a strategy to cope with emotions and are likely to use the same maladaptive emotional eating later in their lives ${ }^{(111,113)}$. Finally, it is strongly supported that certain parenting styles, such as the authority and permissive parenting style, increase the risk of overweight $^{(59,114)}$, especially those children who fail to delay gratification or have poor self-regulation ${ }^{(115)}$. Indeed, it has been suggested that ER mediates the relationship of parental attachment with emotional eating or unhealthy food consumption and sedentary activities in children ${ }^{(87,112)}$.

Lifestyle: a mediator between emotional dysregulation and obesity

Stress and negative affect are linked to other aspects of obesityrelated lifestyle like sedentary behaviour and low physical activity. Children and adolescents with stress or negative affect may perform less physical activity due to decreased motivation and are likely to spend more time on sedentary activities like video games, Internet and television ${ }^{(98,116,117)}$. A recent review suggests that cognitive abilities and self-regulation may enhance active or inactive physical activity behaviours ${ }^{(118)}$. Indeed, a failure in ER or self-regulation might predispose to sedentary behaviour whereas successful self-regulation has been associated with more physical activity ${ }^{(65,66)}$. Simultaneously, an individual could perform physical activity to deal with stressful states or negative emotions. In a representative Canadian sample (aged 15 years or over), $40 \%$ reported using exercise for stress coping and these individuals were more likely to use positive coping strategies and less likely to use alcohol or drugs for coping ${ }^{(119)}$. Physical activity could play a role as an adaptive coping strategy and also increase well-being and efficient ER skills in adults ${ }^{(120)}$ and adolescents ${ }^{(121)}$. This effect could be possible through neuro-hormonal mechanisms but also psychological and sociological aspects ${ }^{(122,123)}$ 
Concurrently, stress and disturbed affective states may influence sleep patterns, causing difficulties in falling asleep or sleep disruption ${ }^{(124,125)}$. Indeed, a comprehensive review described the bidirectional relationship between stress and sleep problems and their underlying pathways ${ }^{(126)}$. Ineffective ER strategies appear to be related to sleep disturbances, which reduce sleep quantity and quality. Since sleep problems may be associated with diminished self-regulation of appetite, they can increase the risk of overeating and obesity ${ }^{(126,127)}$. In the other direction, sleep also plays a role in regulating cognitive and emotional processes. Poor sleep may negatively affect the ability of perception, processing and understanding emotional stimuli $^{(126,128)}$. A recent laboratory study showed that sleep loss affects adequate attention resources during an emotional $\operatorname{task}^{(128)}$. As a consequence, adequate sleep patterns could ameliorate negative emotions and be helpful in ER.

\section{Enhancing emotion-regulation skills for prevention and treatment of obesity}

\section{Interventions in adults}

Several intervention studies and randomised controlled trials have recently been conducted in adults to test the effectiveness of ER strategies in regulating obesity and food intake ${ }^{(129)}$. The most frequent strategies are based on the regulatory skills and correspond to new approaches within the cognitivebehavioural psychological therapies. So, mindfulness therapy, acceptance and commitment therapy, self-compassion therapy (loving-kindness therapy), emotionally focused therapy and dialectical behaviour therapy lead to less psychological distress $^{(130-134)}$, fewer binge eating episodes ${ }^{(130,131,135)}$, less emotional eating ${ }^{(136)}$, fewer food cravings $^{(136-138)}$, healthier eating patterns $^{(131,139)}$, weight loss ${ }^{(131,132,134,138)}$, fewer personal barriers to physical activity ${ }^{(140)}$, and improved self-efficacy to weight $\operatorname{loss}^{(141)}$. Despite a few non-significant findings ${ }^{(142)}$, these strategies are a promising approach for obesity treatment and prevention.

\section{Mechanisms of intervention}

Mindfulness therapy encourages individuals to be nonjudgmentally aware of and to understand their emotions so that they can avoid maladaptive ER such as emotional eating ${ }^{(137)}$. Acceptance therapy could reduce frustration and food preoccupation because it increases the ability to tolerate aversive internal experiences (i.e. anger or sadness) ${ }^{(132)}$. Similarly to these therapies, dialectical behaviour therapy and emotionally focused therapy enhance identification, enabling individuals to accept and modify emotions adaptively. Self-compassion therapy is related to self-support and can help to reduce the sense of threat and stimulate a self-soothing system ${ }^{(143)}$.

The skills used in the several types of therapies are interrelated, and other individual positive factors should be encouraged simultaneously, such as self-empathy, self-esteem, assertiveness, self-efficacy and resilience. For example, selfcompassion and mindfulness are related to lower self-criticism since they enhance self-kindness, self-acceptance, self-empathy and self-esteem ${ }^{(39)}$. Through self-empathy, we develop a concern for our well-being, learn to be sensitive and tolerant of our distress, and develop a deep understanding of its roots and causes. Self-empathy is negatively associated with negative affect and stress and could help us to deal with weight and food stress in a non-judgemental/critical way and to develop selfwarmth $^{(143)}$. Self-esteem also could be a mediator between emotional disorders and obesity ${ }^{(144)}$, since low self-esteem in childhood predicts weight gain ${ }^{(24)}$. So, good self-esteem could help to enhance self-encouragement and self-coaching, which enables individuals to modify their emotions and to confront negative situations. Along with these skills, assertiveness could be developed and be useful as a strategy of social relation, selfconfidence and coping. The ability to analyse and actively modify emotions improves emotional self-efficacy, which reduces stress and avoidance of aversive events. In addition, resilience, which is the capacity to deal successfully with disturbances, is related to awareness, acceptance and tolerance; it decreases vulnerability to negative emotion and boosts self-regulation abilities (i.e. impulse control). This emotional resilience and self-efficacy facilitates a disposition to experience emotionally challenging situations with additional opportunities to strengthen ER skills ${ }^{(39)}$. Later, Forman \& Butyn ${ }^{(145)}$ considered the acceptance-based intervention efficacious for weight control in individuals who are more susceptible to eating in response to internal and external cues (for instance, availability of unhealthy food). These skills included an ability to tolerate uncomfortable internal responses and a reduction of pleasure, behavioural commitment to clearly defined values, and conscience of decision-making process ${ }^{(145)}$.

\section{Interventions in children}

Systematic reviews of interventions show that successful childhood obesity interventions should be multidimensional, combining traditional strategies with behavioural and psychological approaches ${ }^{(2)}$. Nevertheless, few interventional studies have focused on emotional factors. One recent review of behavioural interventions reported that only a small number of intervention studies focused on stress management and emotional control training but that these studies were generally effective $^{(146)}$. The latter-mentioned ER techniques have been applied in children and adolescents in the field of mental disorders but not in child obesity. Nevertheless, we have highlighted some intervention studies which could use methods with similar features of ER techniques such as calm down and awareness about feelings and deal with emotion in a healthy way.

In the field of childhood obesity prevention focusing on ER, to our knowledge there is only one pilot study and two ongoing studies ${ }^{(147-149)}$. A school-based pilot intervention translated specific components of a violence and substance abuse programme into a lifestyle intervention. This pilot programme included seven lessons focusing on teaching tools for controlling impulsiveness, recognising and adaptively dealing with stress, and analysing the effectiveness of possible solutions ${ }^{(147)}$. Although it was a short-term and non-randomised controlled study, the result was a significant change in positive attitudes 
toward self-regulation of appetite and positive changes in food and lifestyle ${ }^{(147)}$. A randomised clinical trial and prospective study conducted in 779 adolescents and their parents applied a cognitive-behavioural skills intervention combined with nutrition education and physical activity. The programme included four of fifteen sessions on cognitive reappraisal, emotional and behavioural regulation, stress, coping, goal-setting and overcoming barriers to a healthy lifestyle ${ }^{(149)}$. This intervention indicated a positive impact on physical activity, BMI and psychological outcomes and also after 6 months, the participants had lower $\mathrm{BMI}^{(150)}$. Another school-based intervention study is currently being carried out in toddlers, combining a traditional obesity prevention programme with a programme to enhance self-regulation. The study teaches children tools for behavioural self-regulation and includes a parental intervention ${ }^{(148)}$.

In childhood obesity treatment, successful intervention studies have applied cognitive-behavioural therapy to encourage the development of effective $\mathrm{ER}^{(151-157)}$. One pilot interventional study applied a cognitive-behavioural skills-building programme in primary care services. The programme was carried out through seven telephone and clinical sessions, which included evaluation of emotional responses and behaviour. Although their results did not show an effect on BMI, they observed an increase in physical activity, healthy lifestyle behaviours and nutrition knowledge. Long-term results were mainly attained in children with supportive families ${ }^{(153,154)}$. Another interventional study conducted in thirty-one children aged 6-12 years and their parents showed positive persistent results since anthropometric parameters and energy intake were reduced and family habits and emotional and social problems were improved at 5 years follow-up ${ }^{(152)}$. Although these studies did not include a control group, their results are promising. Indeed, Sacher et $a l^{(156)}$ developed a randomised controlled trial through a multicomponent community-based childhood obesity intervention based on nutritional and behavioural change in 160 obese children and their parents. The intervention showed a reduction in waist circumference and BMI at 6 and 12 months post-intervention. Therefore, both clinical and community settings now support the development of childhood obesity programmes using ER-related skills.

\section{Implications for prevention and treatment}

Our model highlighted the role of ineffective ER in weight gain. Effective ER skills development could reduce vulnerability during emotional problems and distress, and avoid developing maladaptive ER strategies such as unhealthy eating behaviour related to obesity (i.e. emotional eating, sedentary behaviour). Therefore, future studies should urgently explore the impact of ER on obesity prevention and treatment by applying interdisciplinary interventions.

\section{Implications for prevention}

Given that the acquisition of healthy ER and dietary habits starts in infancy, prevention strategies should be implemented early in life and target the promotion of mental health, effective ER techniques and healthy lifestyle habits such as eating behaviour. Learning effective ER skills from an early age (i.e. as awareness and understanding emotions, acceptance of emotional distress and to learn to have a tolerance under frustration and negative feelings) could avoid children acquiring and developing maladaptive ER such as emotional eating when they feel overwhelmed by intense emotions or stressful events. These intervention approaches should be applied along with nutritional interventions through family-based community programmes, in primary care or in schools. Since parenting style and parental modelling influence children's ER and lifestyle, community obesity prevention programmes should provide support to parents for teaching conflict and negative emotion management techniques and also seek to actively involve parents and family members in changing their own behaviour. To integrate this approach into the school setting, teachers can act as health agents and ER, along with healthy eating habits and lifestyle, can be incorporated into the school curriculum. This type of curricular programme should focus on learning and encouraging awareness and understanding of feelings, identifying internal strengths and learning effective ER skills. Of course, ER programmes should be adapted to the children's age and should include working groups for parents, to reinforce the concepts and techniques that children learn in class and to help the parents face difficult situations they may encounter with their children. One such novel ER approach has been proposed for a school-based obesity prevention programme ${ }^{(158,159)}$.

\section{Implications for treatment}

In obesity treatment, public health agents and paediatricians are encouraged to consider traditional weight-loss methods and nutritional recommendations along with ER intervention. Through ER-based intervention, barriers in the treatment progress such as shame and preoccupation with food can be targeted by fostering greater self-soothing, self-esteem, resilience and body acceptance. Additionally, families need to be aware of the emotional distress that overweight children suffer from. Consequently, the family should also be involved in the intervention to learn effective ER and how to resolve potential conflicts with the child.

\section{Limitations in the interpretation of the model}

Since the model presented in this study is intended to illustrate the potential role of ER in the development of obesity, other risk factors in the stress-obesity pathway have not been mentioned. First, it has been assumed that the associations between stress and obesity share genetic factors like polymorphism on the serotonin $5-\mathrm{HT}_{2 \mathrm{C}}$ receptor gene, monoamine oxidase $\mathrm{A}$, serotonin transporter gene or the fat mass and obesity associated gene (FTO gene $)^{(160-162)}$. In addition, a recent review suggested that socio-economic disadvantages and family disharmony are a common starting point for weight gain and psychological distress in children ${ }^{(3)}$. At the same time, several prenatal, perinatal and postnatal factors (for example, toxics exposure, maternal nutrition, maternal stress, maternal 
psychopathology and negative events during early life) have been identified as obesity and/or neurodevelopmental risk factors $^{(161,163,164)}$.

Additionally, due to the multifaceted nature of the concept, ER has been discussed in the literature under other terms such as self-regulation, self-efficacy, effortful control, impulsivity and emotional eating. This lack of consistent terminology has hindered the literature search strategy and interpretation of studies.

\section{Conclusion}

Stress and negative emotions during childhood pose a major threat to public health, since they have been related not only to psychological disease but also to physiological disturbances such as obesity. Our model posits that ER - the process used to cope with negative emotions - is a fundamental link between childhood stress and obesity. The present review enhances knowledge of the mechanistic pathways between ER and eating behaviour and obesity by condensing existing studies to a visual research framework. Stress, combined with ineffective ER, could already be present in childhood and could cause abnormal cortisol patterns, emotional eating, decreased physical activity, increased sedentary behaviour and the onset of sleep problems. A healthy lifestyle, such as physical activity and adequate sleep, could show benefits on ER and in developing adaptive ER strategies. Parents also influence the development of ER and obesity in children, as role models and through their parenting style and parental feeding practice. Effective ER skills could decrease obesity-related unhealthy behaviour and enhance protective factors, which boost mental and physical health. As a result, effective ER could contribute to the prevention and treatment of childhood obesity. Although the literature is limited in child populations, some observational studies but few interventional studies on this relationship have been published whose findings are modest but promising. We proposed that psycho-educative intervention in ER training could increase the efficacy of prevention and treatment programmes of obesity. Therefore, encouraging adaptive ER could be an effective new approach, along with nutritional and physical activity intervention, in the fight against and the treatment of childhood obesity. Also, developing an effective ER could have effects on other health issues such as better well-being and preventing psychological problems in children. Based on the literature addressing the adult population, possible successful therapies include mindfulness-based stress reduction therapy, acceptance and commitment therapy or self-compassion therapy. Furthermore, protective factors could be stimulated, such as resilience, assertiveness, empathy, self-efficacy and selfesteem. Future ER interventions are needed to confirm the validity of this model in children. Scientists in the nutritional area should be encouraged to conduct more interdisciplinary studies on this nutrition- and obesity-related topic.

\section{Acknowledgements}

There is no relevant funding or sponsorship disclosures from any of the authors.
The authors' contributions to the manuscript were as follows: N. M. initiated the research question and approach; E. A. performed the literature searching and wrote the drafted manuscript; N. M., J. C., V. A. and S. D. H. provided supervision and critical revision of the manuscript. All authors read and approved the final version of the manuscript.

All authors declare no conflicts of interest.

\section{References}

1. Lobstein T \& Millstone E (2007) Context for the PorGrow study: Europe's obesity crisis. Obes Rev 8, Suppl. 2, 7-16.

2. Waters E, de Silva-Sanigorski A, Hall BJ, et al. (2011) Interventions for preventing obesity in children. The Cochrane Database of Systematic Reviews 2011, issue 12, CD001871. http://www.mrw.interscience.wiley.com/cochrane/clsysrev/ articles/CD001871/frame.html.

3. Hemmingsson E (2014) A new model of the role of psychological and emotional distress in promoting obesity: conceptual review with implications for treatment and prevention. Obes Rev 15, 769-779.

4. Goodman E \& Whitaker RC (2002) A prospective study of the role of depression in the development and persistence of adolescent obesity. Pediatrics 110, 497-504.

5. Anderson SE, Murray DM, Johnson CC, et al. (2011) Obesity and depressed mood associations differ by race/ethnicity in adolescent girls. Int J Pediatr Obes 6, 69-78.

6. Bradley RH, Houts R, Nader PR, et al. (2008) The relationship between body mass index and behavior in children. J Pediatr 153, 629-634.

7. van Jaarsveld CHM, Fidler JA, Steptoe A, et al. (2009) Perceived stress and weight gain in adolescence: a longitudinal analysis. Obesity (Silver Spring) 17, 2155-2161.

8. Midei AJ \& Matthews KA (2009) Social relationships and negative emotional traits are associated with central adiposity and arterial stiffness in healthy adolescents. Health Psychol 28, 347-353.

9. Tanofsky-Kraff M, Cohen ML, Yanovski SZ, et al. (2006) A prospective study of psychological predictors of body fat gain among children at high risk for adult obesity. Pediatrics 117, 1203-1209.

10. Rofey D, Kolko R, Iosif A, et al. (2009) A longitudinal study of childhood depression and anxiety in relation to weight gain. Child Psychiatry Hum Dev 40, 517-526.

11. Aparicio E, Canals J, Voltas N, et al. (2013) Emotional psychopathology and increased adiposity: follow-up study in adolescents. $J$ Adolesc 36, 319-330.

12. Larsen JK, Otten R, Fisher JO, et al. (2014) Depressive symptoms in adolescence: a poor indicator of increases in body mass index. J Adolesc Health 54, 94-99.

13. Rhew IC, Richardson LP, Lymp J, et al. (2008) Measurement matters in the association between early adolescent depressive symptoms and body mass index. Gen Hosp Psychiatry 30, 458-466.

14. Michels N, Sioen I, Boone L, et al. (2015) Cross-lagged associations between children's stress and adiposity. Psychosom Med 77, 50-58.

15. Stice E, Presnell K, Shaw H, et al. (2005) Psychological and behavioral risk factors for obesity onset in adolescent girls: a prospective study. J Consult Clin Psychol 73, 195-202.

16. Jansen W, van de Looij-Jansen PM, de Wilde EJ, et al. (2008) Feeling fat rather than being fat may be associated with psychological well-being in young Dutch adolescents. $J$ Adolesc Health 42, 128-136. 
17. Chen EY, McCloskey MS \& Keenan KE (2009) Subtyping dietary restraint and negative affect in a longitudinal community sample of girls. Int J Eat Disord 42, 275-283.

18. Hammerton G, Thapar A \& Thapar AK (2014) Association between obesity and depressive disorder in adolescents at high risk for depression. Int J Obes 38, 513-519.

19. Pine DS, Cohen P, Brook J, et al. (1997) Psychiatric symptoms in adolescence as predictors of obesity in early adulthood: a longitudinal study. Am J Public Health 87, 1303-1310.

20. Pine DS, Goldstein RB, Wolk S, et al. (2001) The association between childhood depression and adulthood body mass index. Pediatrics 107, 1049-1056.

21. Franko DL, Striegel-Moore RH, Bean J, et al. (2005) Selfreported symptoms of depression in late adolescence to early adulthood: a comparison of African-American and Caucasian females. J Adolesc Health 37, 526-529.

22. Anderson SE, Cohen P, Naumova EN, et al. (2006) Association of depression and anxiety disorders with weight change in a prospective community-based study of children followed up into adulthood. Arch Pediatr Adolesc Med 160, 285-291.

23. Richardson LP, Davis R, Poulton R, et al. (2003) A longitudinal evaluation of adolescent depression and adult obesity. Arch Pediatr Adolesc Med 157, 739-745.

24. Ternouth A, Collier D \& Maughan B (2009) Childhood emotional problems and self-perceptions predict weight gain in a longitudinal regression model. BMC Med 7, 46.

25. Hasler G, Pine DS, Kleinbaum DG, et al. (2005) Depressive symptoms during childhood and adult obesity: the Zurich Cohort Study. Mol Psychiatry 10, 842-850.

26. Duarte C, Sourander A, Nikolakaros G, et al. (2010) Child mental health problems and obesity in early adulthood. J Pediatr 156, 93-97.

27. Wickrama KA, Wickrama T \& Lott R (2009) Heterogeneity in youth depressive symptom trajectories: social stratification and implications for young adult physical health. $J$ Adolesc Health 45, 335-343.

28. Kieling C, Baker-Henningham H, Belfer M, et al. (2011) Child and adolescent mental health worldwide: evidence for action. Lancet 378, 1515-1525.

29. Vanaelst B, De Vriendt T, Ahrens W, et al. (2012) Prevalence of psychosomatic and emotional symptoms in European school-aged children and its relationship with childhood adversities: results from the IDEFICS study. Eur Child Adolesc Psychiatry 21, 253-265.

30. Aldao A \& Nolen-Hoeksema S (2012) When are adaptive strategies most predictive of psychopathology? J Abnorm Psychol 121, 276-281.

31. Michopoulos V, Powers A, Moore C, et al. (2015) The mediating role of emotion dysregulation and depression on the relationship between childhood trauma exposure and emotional eating. Appetite 91, 129-136.

32. Evers C, Marijn Stok F \& de Ridder DTD (2010) Feeding your feelings: emotion regulation strategies and emotional eating. Pers Soc Psychol Bull 36, 792-804.

33. Taut D, Renner B \& Baban A (2012) Reappraise the situation but express your emotions: impact of emotion regulation strategies on ad libitum food intake. Front Psychol 3, 359.

34. Gross JJ (2015) Emotion regulation : current status and future prospects. Psychol Inq 26, 1-26.

35. Compas BE, Jaser SS, Dunbar JP, et al. (2014) Coping and emotion regulation from childhood to early adulthood: points of convergence and divergence. Aust J Psychol 66, $71-81$.

36. Gross JJ (2013) Emotion regulation: taking stock and moving forward. Emotion 13, 359-365.
37. Thompson R (1994) Emotion regulation: a theme in search of definition. Monogr Soc Res Child Dev 59, 25-52.

38. Gross J (1998) The emerging field of emotion regulation: an integrative review. Rev Gen Psychol 2, 271-299.

39. Berking M \& Whitley B (2014) Affect Regulation Training. New York: Springer New York.

40. Royall DR, Lauterbach EC, Cummings JL, et al. (2002) Executive control function: a review of its promise and challenges for clinical research. A report from the Committee on Research of the American Neuropsychiatric Association. J Neuropsychiatry Clin Neurosci 14, 377-405.

41. Gyurak A, Goodkind MS, Kramer JH, et al. (2013) Executive functions and the down-regulation and up-regulation of emotion. Cogn Emot 26, 103-118.

42. Fitzpatrick S, Gilbert S \& Serpell L (2013) Systematic review: are overweight and obese individuals impaired on behavioural tasks of executive functioning? Neuropsychol Rev $\mathbf{2 3}$, 138-156.

43. Schwartz DH, Leonard G, Perron M, et al. (2013) Visceral fat is associated with lower executive functioning in adolescents. Int J Obes (Lond) 37, 1336-1343.

44. Blanco-Gómez A, Ferré N, Luque V, et al. (2015) Being overweight or obese is associated with inhibition control in children from six to ten years of age. Acta Paediatr 104, 619-625.

45. Groppe K \& Elsner B (2014) Executive function and food approach behavior in middle childhood. Front Psychol 5, 447.

46. Dempsey A, Dyehouse J \& Schafer J (2011) The relationship between executive function, $\mathrm{AD} / \mathrm{HD}$, overeating, and obesity. West J Nurs Res 33, 609-629.

47. Erhart M, Herpertz-Dahlmann B, Wille N, et al. (2012) Examining the relationship between attention-deficit/ hyperactivity disorder and overweight in children and adolescents. Eur Child Adolesc Psychiatry 21, 39-49.

48. Johnson F, Pratt M \& Wardle J (2012) Dietary restraint and self-regulation in eating behavior. Int J Obes (Lond) $\mathbf{3 6}$, 665-674.

49. Batterink L, Yokum S \& Stice E (2010) Body mass correlates inversely with inhibitory control in response to food among adolescent girls: an fMRI study. NeuroImage 52, 1696-1703.

50. Francis LA \& Susman EJ (2009) Self-regulation and rapid weight gain in children from age 3 to 12 years. Arch Pediatr Adolesc Med 163, 297-302.

51. Graziano PA, Calkins SD \& Keane SP (2010) Toddler selfregulation skills predict risk for pediatric obesity. Int J Obes (Lond) 34, 633-641.

52. Graziano PA, Kelleher R, Calkins SD, et al. (2013) Predicting weight outcomes in preadolescence: the role of toddlers' self-regulation skills and the temperament dimension of pleasure. Int J Obes (Lond) 37, 937-942.

53. Pauli-Pott U, Albayrak O, Hebebrand J, et al. (2010) Association between inhibitory control capacity and body weight in overweight and obese children and adolescents: dependence on age and inhibitory control component. Child Neuropsychol 16, 592-603.

54. Perez-Pereira M, Fernandez P, Gómez-Taibo M, et al. (2013) Neurobehavioral development of preterm and full term children: biomedical and environmental influences. Early Hum Dev 89, 401-409.

55. Zeman J, Cassano M, Perry-Parrish C, et al. (2006) Emotion regulation in children and adolescents. J Dev Behav Pediatr 27, 155-168.

56. Morris AS, Silk JS, Steinberg L, et al. (2007) The role of the family context in the development of emotion regulation. Soc Dev 16, 361-388. 
57. Gresham D \& Gullone E (2012) Emotion regulation strategy use in children and adolescents: the explanatory roles of personality and attachment. Personal Individ Differ 52, 616-621.

58. Jones S, Eisenberg N, Fabes RA, et al. (2002) Parents' reactions to elementary school children's negative emotions: relations to social and emotional functioning at school. Merrill Palmer Q 48, 133-159.

59. Baumrind D, Larzelere RE \& Owens EB (2010) Effects of preschool parents' power assertive patterns and practices on adolescent development. Parenting 10, 157-201.

60. Dickstein DP \& Leibenluft E (2006) Emotion regulation in children and adolescents: boundaries between normalcy and bipolar disorder. Dev Psychopathol 18, 1105-1131.

61. Wills TA, Pokhrel P, Morehouse E, et al. (2011) Behavioral and emotional regulation and adolescent substance use problems: a test of moderation effects in a dualprocess model. Psychol Addict Behav 25, 279-292.

62. Braet C, Theuwis L, Van Durme K, et al. (2014) Emotion regulation in children with emotional problems. Cognit Ther Res 38, 493-504.

63. Berking M, Poppe C, Luhmann M, et al. (2012) Is the association between various emotion-regulation skills and mental health mediated by the ability to modify emotions? Results from two cross-sectional studies. J Behav Ther Exp Psychiatry 43, 931-937.

64. Wedig MM \& Nock MK (2010) The functional assessment of maladaptive behaviors: a preliminary evaluation of binge eating and purging among women. Psychiatry Res 178, 518-524.

65. Isasi CR, Ostrovsky NW \& Wills T (2013) The association of emotion regulation with lifestyle behaviors in inner-city adolescents. Eat Behav 14, 518-521.

66. Isasi C \& Wills T (2011) Behavioral self-regulation and weight-related behaviors in inner-city adolescents: a model of direct and indirect effects. Child Obes 7, 306-315.

67. Wills T, Isasi CR, Mendoza D, et al. (2007) Self-control constructs related to measures of dietary intake and physical activity in adolescents. I Adolesc Health 41, 551-558.

68. Riggs N, Chou C-P, Spruijt-Metz D, et al. (2010) Executive cognitive function as a correlate and predictor of child food intake and physical activity. Child Neuropsychol 16, 279-292.

69. Riggs NR, Spruijt-Metz D, Chou C-P, et al. (2012) Relationships between executive cognitive function and lifetime substance use and obesity-related behaviors in fourth grade youth. Child Neuropsychol 18, 1-11.

70. Riggs NR, Spruijt-Metz D, Sakuma K-L, et al. (2010) Executive cognitive function and food intake in children. $J$ Nutr Educ Behav 42, 398-403.

71. Hughes SO, Power TG, O'Connor TM, et al. (2015) Executive functioning, emotion regulation, eating self-regulation, and weight status in low-income preschool children: how do they relate? Appetite 89, 1-9.

72. Pervanidou P \& Chrousos GP (2011) Metabolic consequences of stress during childhood and adolescence. Metabolism 61, 611-619.

73. Charmandari E, Tsigos C \& Chrousos G (2005) Endocrinology of the stress response. Annu Rev Physiol 67, 259-284.

74. Peckett AJ, Wright DC \& Riddell MC (2011) The effects of glucocorticoids on adipose tissue lipid metabolism. Metabolism 60, 1500-1510.

75. Miller GE, Chen E \& Zhou ES (2007) If it goes up, must it come down? Chronic stress and the hypothalamic-pituitaryadrenocortical axis in humans. Psychol Bull 133, 25-45.
76. Michels N, Sioen I, Braet C, et al. (2013) Relation between salivary cortisol as stress biomarker and dietary pattern in children. Psychoneuroendocrinology 38, 1512-1520.

77. Cris LG, Opre A \& Miu AC (2015) Emotional non-acceptance links early life stress and blunted cortisol reactivity to social threat. Psychoneuroendocrinology 51, 176-187.

78. Dallman MF, Pecoraro N, Akana SF, et al. (2003) Chronic stress and obesity: a new view of 'comfort food'. Proc Natl Acad Sci U S A 100, 11696-11701.

79. Bruch H (1973) Eating Disorders: Obesity, Anorexia Nervosa, and the Person Within. New York: Basic Books.

80. Spoor STP, Bekker MHJ, Van Strien T, et al. (2007) Relations between negative affect, coping, and emotional eating. Appetite 48, 368-376.

81. Goossens L, Braet C, Van Vlierberghe L, et al. (2009) Loss of control over eating in overweight youngsters: the role of anxiety, depression and emotional eating. Eur Eat Disord Rev 17, 68-78.

82. Michels N, Sioen I, Braet C, et al. (2012) Stress, emotional eating behaviour and dietary patterns in children. Appetite 59, 762-769.

83. Czaja J, Rief W \& Hilbert A (2009) Emotion regulation and binge eating in children. Int J Eat Disord 42, 356-362.

84. Martyn-Nemeth P, Penckofer S, Gulanick M, et al. (2009) The relationships among self-esteem, stress, coping, eating behavior, and depressive mood in adolescents. Res Nurs Heal 32, 96-109.

85. Braet C \& van Strien T (1997) Assessment of emotional, externally induced and restrained eating behaviour in nine to twelve-year-old obsese and non-obese children. Behav Res Ther 35, 863-873.

86. Harrist AW, Hubbs-Tait L, Topham GL, et al. (2013) Emotion regulation is related to children's emotional and external eating. J Dev Behav Pediatr 34, 557-565.

87. Vandewalle J, Moens E \& Braet C (2014) Comprehending emotional eating in obese youngsters: the role of parental rejection and emotion regulation. Int J Obes (Lond) $\mathbf{3 8}$, 525-530.

88. Kubiak T, Vögele C, Siering M, et al. (2008) Daily hassles and emotional eating in obese adolescents under restricted dietary conditions - the role of ruminative thinking. Appetite 51, 206-209.

89. Gibson EL (2006) Emotional influences on food choice: sensory, physiological and psychological pathways. Physiol Behav 89, 53-61.

90. Konttinen H, Männistö S, Sarlio-Lähteenkorva S, et al. (2010) Emotional eating, depressive symptoms and self-reported food consumption. A population-based study. Appetite 54, 473-479.

91. Camilleri GM, Méjean C, Kesse-Guyot E, et al. (2014) The associations between emotional eating and consumption of energy-dense snack foods are modified by sex and depressive symptomatology. J Nutr 144, 1264-1273.

92. Péneau S, Ménard E, Méjean C, et al. (2013) Sex and dieting modify the association between emotional eating and weight status. Am J Clin Nutr 97, 1307-1313.

93. Oliver G, Wardle J \& Gibson EL (2000) Stress and food choice: a laboratory study. Psychosom Med 62, 853-865.

94. van Strien T, Cebolla A, Etchemendy E, et al. (2013) Emotional eating and food intake after sadness and joy. Appetite 66, 20-25.

95. Wallis DJ \& Hetherington MM (2009) Emotions and eating. Self-reported and experimentally induced changes in food intake under stress. Appetite 52, 355-362.

96. Elfhag K, Tholin S \& Rasmussen F (2008) Consumption of fruit, vegetables, sweets and soft drinks are associated with 
psychological dimensions of eating behaviour in parents and their 12-year-old children. Public Health Nutr 11, 914-923.

97. Nguyen-Michel ST, Unger JB \& Spruijt-Metz D (2007) Dietary correlates of emotional eating in adolescence. Appetite 49, 494-499.

98. Ouwens MA, Cebolla A \& van Strien T (2012) Eating style, television viewing and snacking in pre-adolescent children. Nutr Hosp 27, 1072-1078.

99. Moens E \& Braet C (2007) Predictors of disinhibited eating in children with and without overweight. Behav Res Ther $\mathbf{4 5}$, 1357-1368.

100. Ouwens MA, van Strien T, van Leeuwe JF, et al. (2009) The dual pathway model of overeating. Replication and extension with actual food consumption. Appetite 52, 234-237.

101. Goldschmidt AB, Tanofsky-Kraff M \& Wilfley DE (2011) A laboratory-based study of mood and binge eating behavior in overweight children. Eat Behav 12, 37-43.

102. van Strien T, Herman CP \& Verheijden MW (2012) Eating style, overeating and weight gain. A prospective 2-year follow-up study in a representative Dutch sample. Appetite 59, 782-789.

103. Koenders PG \& van Strien T (2011) Emotional eating, rather than lifestyle behavior, drives weight gain in a prospective study in 1562 employees. J Occup Environ Med 53, $1287-1293$.

104. Snoek HM, van Strien T, Janssens JMAM, et al. (2007) Emotional, external, restrained eating and overweight in Dutch adolescents. Scand J Psychol 48, 23-32.

105. Braet C, Claus L, Goossens L, et al. (2008) Differences in eating style between overweight and normal-weight youngsters. J Health Psychol 13, 733-743.

106. Eddy KT, Tanofsky-Kraff M, Thompson-Brenner $\mathrm{H}$, et al. (2007) Eating disorder pathology among overweight treatment-seeking youth: clinical correlates and crosssectional risk modeling. Behav Res Ther 45, 2360-2371.

107. Kaplan HI \& Kaplan HS (1957) The psychosomatic concept of obesity. J Nerv Ment Dis 125, 181-201.

108. Skeer MR \& Ballard EL (2013) Are family meals as good for youth as we think they are? A review of the literature on family meals as they pertain to adolescent risk prevention. I Youth Adolesc 42, 943-963.

109. Wehrly SE, Bonilla C, Perez M, et al. (2014) Controlling parental feeding practices and child body composition in ethnically and economically diverse preschool children. Appetite 73, 163-171.

110. Rodgers RF, Paxton SJ, Massey R, et al. (2013) Maternal feeding practices predict weight gain and obesogenic eating behaviors in young children: a prospective study. Int J Behav Nutr Phys Act 10, 24.

111. Blissett J, Haycraft E \& Farrow C (2010) Inducing preschool children's emotional eating: relations with parental feeding practices. Am J Clin Nutr 92, 359-365.

112. Bost KK, Wiley AR, Fiese B, et al. (2014) Associations between adult attachment style, emotion regulation, and preschool children's food consumption. J Dev Behav Pediatr 35, 50-61.

113. Kröller K, Jahnke D \& Warschburger P (2013) Are maternal weight, eating and feeding practices associated with emotional eating in childhood? Appetite 65, 25-30.

114. Latzer Y \& Stein D (2013) A review of the psychological and familial perspectives of childhood obesity. J Eat Disord 1, 7.

115. Connell LE \& Francis LA (2014) Positive parenting mitigates the effects of poor self-regulation on body mass index trajectories from ages 4-15 years. Health Psychol 33, 757-764.

116. Anton SD, Newton RL, Sothern M, et al. (2006) Association of depression with body mass index, sedentary behavior, and maladaptive eating attitudes and behaviors in 11 to 13-year old children. Eat Weight Disord 11, e102-e108.

117. Reeves GM, Postolache TT \& Snitker S (2008) Childhood obesity and depression: connection between these growing problems in growing children. Int J Child Health Hum Dev $\mathbf{1}$, 103-114.

118. Buckley J, Cohen JD, Kramer AF, et al. (2014) Cognitive control in the self-regulation of physical activity and sedentary behavior. Front Hum Neurosci 8, 747.

119. Cairney J, Kwan MY, Veldhuizen S, et al. (2014) Who uses exercise as a coping strategy for stress? Results from a national survey of Canadians. J Phys Act Heal 11, 908-916.

120. Hegberg NJ \& Tone EB (2015) Physical activity and stress resilience: considering those at-risk for developing mental health problems. Ment Health Phys Act 8, 1-7.

121. Ho FKW, Louie LHT, Chow CB, et al. (2015) Physical activity improves mental health through resilience in Hong Kong Chinese adolescents. BMC Pediatr 15, 48.

122. Monshouwer K, ten Have M, van Poppel M, et al. (2012) Possible mechanisms explaining the association between physical activity and mental health: findings from the 2001 Dutch Health Behaviour in School-Aged Children Survey. Clin Psychol Sci 1, 67-74.

123. Rees DI \& Sabia JJ (2010) Exercise and adolescent mental health: new evidence from longitudinal data. J Ment Health Policy Econ 13, 13-25.

124. Morin CM, Rodrigue S \& Ivers H (2003) Role of stress, arousal, and coping skills in primary insomnia. Psychosom Med 65, 259-267.

125. Vandekerckhove M, Weiss R, Schotte C, et al. (2011) The role of presleep negative emotion in sleep physiology. Psychophysiology 48, 1738-1744.

126. Kahn M, Sheppes G \& Sadeh A (2013) Sleep and emotions: bidirectional links and underlying mechanisms. Int $J$ Psychophysiol 89, 218-228.

127. Burt J, Dube L, Thibault L, et al. (2014) Sleep and eating in childhood: a potential behavioral mechanism underlying the relationship between poor sleep and obesity. Sleep Med $\mathbf{1 5}$, 71-75.

128. Alfarra R, Fins AI, Chayo I, et al. (2015) Changes in attention to an emotional task after sleep deprivation: neurophysiological and behavioral findings. Biol Psychol 104, 1-7.

129. O'Reilly GA, Cook L, Spruijt-Metz D, et al. (2014) Mindfulness-based interventions for obesity-related eating behaviours: a literature review. Obes Rev 15, 453-461.

130. Compare A, Calugi S, Marchesini G, et al. (2013) Emotionally focused group therapy and dietary counseling in binge eating disorder. Effect on eating disorder psychopathology and quality of life. Appetite 71, 361-368.

131. Dalen J, Smith BW, Shelley BM, et al. (2010) Pilot study: Mindful Eating and Living (MEAL): weight, eating behavior, and psychological outcomes associated with a mindfulnessbased intervention for people with obesity. Complement Ther Med 18, 260-264.

132. Forman EM, Butryn ML, Hoffman KL, et al. (2009) An open trial of an acceptance-based behavioral intervention for weight loss. Cogn Behav Pract 16, 223-235.

133. Daubenmier J, Kristeller J, Hecht FM, et al. (2011) Mindfulness intervention for stress eating to reduce cortisol and abdominal fat among overweight and obese women: an exploratory randomized controlled study. $J$ Obes 2011, 651936.

134. Mantzios M \& Wilson J (2015) Exploring mindfulness and mindfulness with self-compassion-centered interventions to assist weight loss: theoretical considerations and preliminary results of a randomized pilot study. Mindfulness 6, 824-835. 
135. Wiser S \& Telch CF (1999) Dialectical behavior therapy for binge-eating disorder. J Clin Psychol 55, 755-768.

136. Alberts HJEM, Thewissen R \& Raes L (2012) Dealing with problematic eating behaviour. The effects of a mindfulnessbased intervention on eating behaviour, food cravings, dichotomous thinking and body image concern. Appetite 58, 847-851.

137. Alberts HJEM, Mulkens S, Smeets M, et al. (2010) Coping with food cravings. Investigating the potential of a mindfulness-based intervention. Appetite 55, 160-163.

138. Forman EM, Hoffman KL, Juarascio AS, et al. (2013) Comparison of acceptance-based and standard cognitive-based coping strategies for craving sweets in overweight and obese women. Eat Behav 14, 64-68.

139. Miller C, Kristeller J, Headings A, et al. (2012) Comparative effectiveness of a mindful eating intervention to a diabetes self-management intervention among adults with type 2 diabetes: a pilot study. J Acad Nutr Diet 112, 1835-1842.

140. Tapper K, Shaw C, Ilsley J, et al. (2009) Exploratory randomised controlled trial of a mindfulness-based weight loss intervention for women. Appetite 52, 396-404.

141. Kidd LI, Graor CH \& Murrock CJ (2013) A mindful eating group intervention for obese women: a mixed methods feasibility study. Arch Psychiatr Nurs 27, 211-218.

142. Kearney DJ, Milton ML, Malte CA, et al. (2012) Participation in mindfulness-based stress reduction is not associated with reductions in emotional eating or uncontrolled eating. Nutr Res 32, 413-420.

143. Gilbert P \& Procter S (2006) Compassionate mind training for people with high shame and self-criticism: overview and pilot study of a group therapy approach. Clin Psychol Psychother 379, 353-379.

144. Cortese S, Falissard B, Angriman M, et al. (2009) The relationship between body size and depression symptoms in adolescents. J Pediatr 154, 86-90.

145. Forman EM \& Butryn ML (2015) A new look at the science of weight control: how acceptance and commitment strategies can address the challenge of self-regulation. Appetite $\mathbf{8 4}$, 171-180.

146. Martin J, Chater A \& Lorencatto F (2013) Effective behaviour change techniques in the prevention and management of childhood obesity. Int J Obes (Lond) 37, 1287-1294.

147. Riggs NR, Sakuma K-LK \& Pentz MA (2007) Preventing risk for obesity by promoting self-regulation and decision-making skills: pilot results from the PATHWAYS to health program (PATHWAYS). Eval Rev 31, 287-310.

148. Miller AL, Horodynski MA, Herb HE, et al. (2012) Enhancing self-regulation as a strategy for obesity prevention in Head Start preschoolers: the growing healthy study. BMC Public Health 12, 1040.

149. Melnyk BM, Kelly S, Jacobson D, et al. (2013) The COPE healthy lifestyles TEEN randomized controlled trial with culturally diverse high school adolescents: baseline characteristics and methods. Contemp Clin Trials 36, 41-53.
150. Melnyk BM, Jacobson D, Kelly S, et al. (2013) Promoting healthy lifestyles in high school adolescents: a randomized controlled trial. Am J Prev Med 45, 407-415.

151. Boutelle KN, Kuckertz JM, Carlson J, et al. (2014) A pilot study evaluating a one-session attention modification training to decrease overeating in obese children. Appetite 76, 180-185.

152. Vignolo M, Rossi F, Bardazza G, et al. (2008) Five-year follow-up of a cognitive-behavioural lifestyle multidisciplinary programme for childhood obesity outpatient treatment. Eur J Clin Nutr 62, 1047-1057.

153. Jacobson D \& Melnyk BM (2012) A primary care healthy choices intervention program for overweight and obese school-age children and their parents. J Pediatr Health Care 26, 126-138.

154. Jacobson D \& Melnyk BM (2011) Psychosocial correlates of healthy beliefs, choices, and behaviors in overweight and obese school-age children: a primary care healthy choices intervention pilot study. I Pediatr Nurs 26, 456-464.

155. Halberstadt J, Makkes S, de Vet E, et al. (2013) The role of self-regulating abilities in long-term weight loss in severely obese children and adolescents undergoing intensive combined lifestyle interventions (HELIOS); rationale, design and methods. BMC Pediatr 13, 41.

156. Sacher PM, Kolotourou M, Chadwick PM, et al. (2010) Randomized controlled trial of the MEND program: a family-based community intervention for childhood obesity. Obesity (Silver Spring) 18, Suppl. 1, S62-S68.

157. Moore SM, Borawski EA, Cuttler L, et al. (2013) IMPACT: a multi-level family and school intervention targeting obesity in urban youth. Contemp Clin Trials 36, 574-586.

158. Sakuma KLK, Riggs NR \& Pentz MA (2012) Translating evidence based violence and drug use prevention to obesity prevention: development and construction of the Pathways program. Health Educ Res 27, 343-358.

159. Pentz MA (2014) Integrating mindfulness into school-based substance use and other prevention programs. Subst Use Misuse 49, 617-619.

160. Fuemmeler BF, Agurs-Collins T, McClernon FJ, et al. (2009) Interactions between genotype and depressive symptoms on obesity. Behav Genet 39, 296-305.

161. Wermter AK, Laucht M, Schimmelmann BG, et al. (2010) From nature versus nurture, via nature and nurture, to gene $\mathrm{x}$ environment interaction in mental disorders. Eur Child Adolesc Psychiatry 19, 199-210.

162. Velders FP, De Wit JE, Jansen PW, et al. (2012) FTO at rs9939609, food responsiveness, emotional control and symptoms of ADHD in preschool children. PLOS ONE 7, e49131.

163. Provençal N \& Binder EB (2015) The effects of early life stress on the epigenome: from the womb to adulthood and even before. Exp Neurol 268, 10-20.

164. Entringer S, Buss C, Swanson JM, et al. (2012) Fetal programming of body composition, obesity, and metabolic function: the role of intrauterine stress and stress biology. J Nutr Metab 2012, 632548 